\title{
Assessing Predictability of Cotton Yields in the Southeastern United States Based on Regional Atmospheric Circulation and Surface Temperatures
}

\author{
Guillermo A. BAigorria \\ Agricultural and Biological Engineering Department, University of Florida, Gainesville, Florida \\ James W. Hansen AND NeIL Ward \\ International Research Institute for Climate and Society, The Earth Institute at Columbia University, Palisades, New York \\ JAMES W. JONES \\ Agricultural and Biological Engineering Department, University of Florida, Gainesville, Florida \\ JAMES J. O'BRIEN \\ Center for Ocean-Atmospheric Prediction Studies, The Florida State University, Tallahassee, Florida
}

(Manuscript received 28 June 2006, in final form 19 March 2007)

\begin{abstract}
The potential to predict cotton yields up to one month before planting in the southeastern United States is assessed in this research. To do this, regional atmospheric variables that are related to historic summer rainfall and cotton yields were identified. The use of simulations of those variables from a global circulation model (GCM) for estimating cotton yields was evaluated. The authors analyzed detrended cotton yields (1970-2004) from 48 counties in Alabama and Georgia, monthly rainfall from 53 weather stations, monthly reanalysis data of 850 - and $200-\mathrm{hPa}$ winds and surface temperatures over the southeast U.S. region, and monthly predictions of the same variables from the ECHAM $4.5 \mathrm{GCM}$. Using the reanalysis climate data, it was found that meridional wind fields and surface temperatures around the Southeast were significantly correlated with county cotton yields (explaining up to $52 \%$ of the interannual variability of observed yields), and with rainfall over most of the region, especially during April and July. The tendency for cotton yields to be lower during years with atmospheric circulation patterns that favor higher humidity and rainfall is consistent with increased incidence of disease in cotton during flowering and harvest periods under wet conditions. Cross-validated yield estimations based on ECHAM retrospective simulations of wind and temperature fields forced by observed SSTs showed significant predictability skill (up to $55 \%$ and $60 \%$ hit skill scores based on terciles and averages, respectively). It is concluded that there is potential to predict cotton yields in the Southeast by using variables that are forecast by numerical climate models.
\end{abstract}

\section{Introduction}

Climate variability is a major source of production risks in agriculture. According to Ibarra and Hewitt (1999), the majority of crop failures in the United States are associated with either a lack of or an excess of rainfall. Climate variability is also associated with other sources of production risks, such as yield losses to pests

Corresponding author address: Guillermo A. Baigorria, 256 Frazier Rogers Hall, Agricultural and Biological Engineering Dept., University of Florida, Gainesville, FL 32611-0570.

E-mail: gbaigorr@ifas.ufl.edu and diseases. High temperature, humidity, and rainfall can create a favorable environment for fungal diseases (Fraisse et al. 2006).

One way to reduce agricultural vulnerability to climate variability is through the use of skillful seasonal climate forecasts. If farmers know what the next cropping season's climate will be, they may be able to adjust their management to increase yield or income, increase efficiency of agricultural inputs, and decrease chemical losses to the environment. Yield prediction based on climate forecasts could be used to evaluate options available for management and marketing of the next crop (Hansen 2002, 2005; Ingram et al. 2002; Jagtap et 
al. 2002; Nelson et al. 2002; Phillips et al. 2002; Podestá et al. 2002). However, to realize this potential use of climate forecasts, farmers need to know how reliable they are and how the use of the forecasts will change their risks. One method that is gaining increasing attention is the use of global (or regional) circulation models (GCMs or RCMs). Previous research has demonstrated the use of GCM/RCM climate forecasts to predict crop yields through empirical relationships. These methods, for example, develop statistical crop yield models using sea surface temperatures (SSTs), probability-weighted historical analogs, stochastic disaggregation of GCM climate outputs (Hansen and Indeje 2004), or regional climate patterns (Hansen et al. 1998; Hsieh et al. 1999; Challinor et al. 2003).

Another approach is to link process-based crop models with seasonal climate forecasts. When daily GCM/ RCM outputs are used, temporal downscaling is not necessary and the outputs can be used directly (Challinor et al. 2005; Marletto et al. 2005; Shin et al. 2006) or adjusted in some way before using them as input to crop models (Ines and Hansen 2006; Baigorria et al. 2006). However, when GCM/RCMs forecasts are summarized as monthly values, these must be disaggregated to daily values to match inputs needed by the crop models. For example, monthly raw or corrected GCM/RCM outputs are used with weather generators to producedaily weather data needed by crop models (Baigorria 2007; Baigorria et al. 2007b; Cantelaube and Terres 2005).

A GCM integrates the influences of global SSTs on climate, thus it may have the potential to predict largescale circulation patterns that influence local rainfall and crop yields (Higgins et al. 1998; Davis et al. 1997; Stahle and Cleaveland 1992). In cases where a direct relationship is well established between a meteorological variable (rainfall in monsoon climates for instance) and crop yields, it is possible to use it for forecasting purposes (Challinor et al. 2003). However, such rainfall-crop yield relationships are not always available. Therefore, it may be necessary to analyze climate and crop yield variability together to better understand physical and biological process teleconnections.

Cotton is one of the most important crops grown across the southeast United States. Its production was valued at $\$ 455$ million in 2002 in Alabama and Georgia (USDA National Agricultural Statistics Service 2004 ${ }^{1}$ ). In the last $30 \mathrm{yr}$, cotton cultivation increased by 800000 ha in the United States. Much of this increase occurred in the Southeast where yields have also increased dur-

\footnotetext{
${ }^{1}$ This is the last year U.S. Department of Agriculture/National Agircultural Statistics Service published statistics of production values in the United States.
}

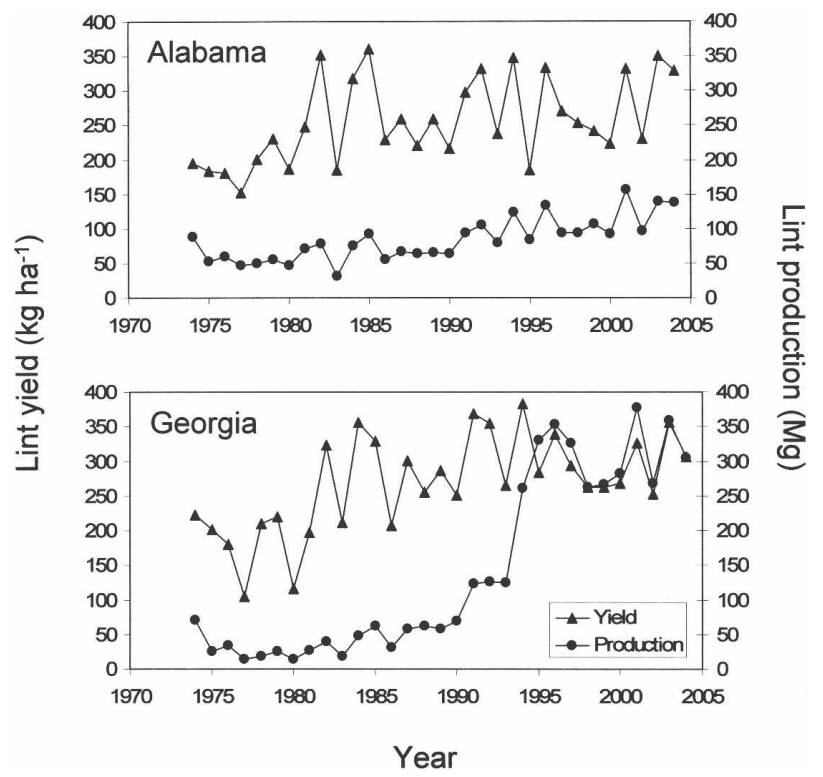

FIG. 1. Yearly cotton (lint) yield and total fiber (lint) production in (top) Alabama and (bottom) Georgia.

ing this period. U.S. cotton exports have more than doubled in the last 5 yr (Goodman 2004). However, annual cotton yields and total production in Alabama, Florida, and Georgia have varied considerably during the last $30 \mathrm{yr}$ (see Fig. 1 for Alabama and Georgia trends). Figure 2 shows the locations and average yields of counties that have produced cotton consistently during the last $30 \mathrm{yr}$ in these states.

Cotton yields can be decreased both by drought conditions and by diseases associated with wet and humid conditions during the six- to eight-week flowering window, and during the boll maturity period. Hardlock of cotton is a yield-reducing disease mainly associated with the fungus Fusarium verticillioides (Mailhot et al. 2005; Marois et al. 2002, 2005) that causes fibers to bond into a hard shape instead of fluffing out as the boll matures (Jost et al. 2005). In 2002, hardlock reduced yield by about $50 \%$ in the Florida Panhandle (about $\$ 20$ million in losses). Boll rot, also associated with wet and humid conditions, is caused by a complex of fungal and bacterial pathogens colonizing the cotton fiber during boll opening and harvesting periods (Jost et al. 2005; Marois et al. 2002). The most critical periods when drought reduces yield are (i) before and during bloom, reducing the number of fruiting branches and flowers, and (ii) during boll maturation when drought causes the highest losses of cotton yield and quality (Jost et al. 2005).

The overall goal of our research is to evaluate the potential use of numerical climate forecasts from a GCM to estimate yields of summer crops in the South- 


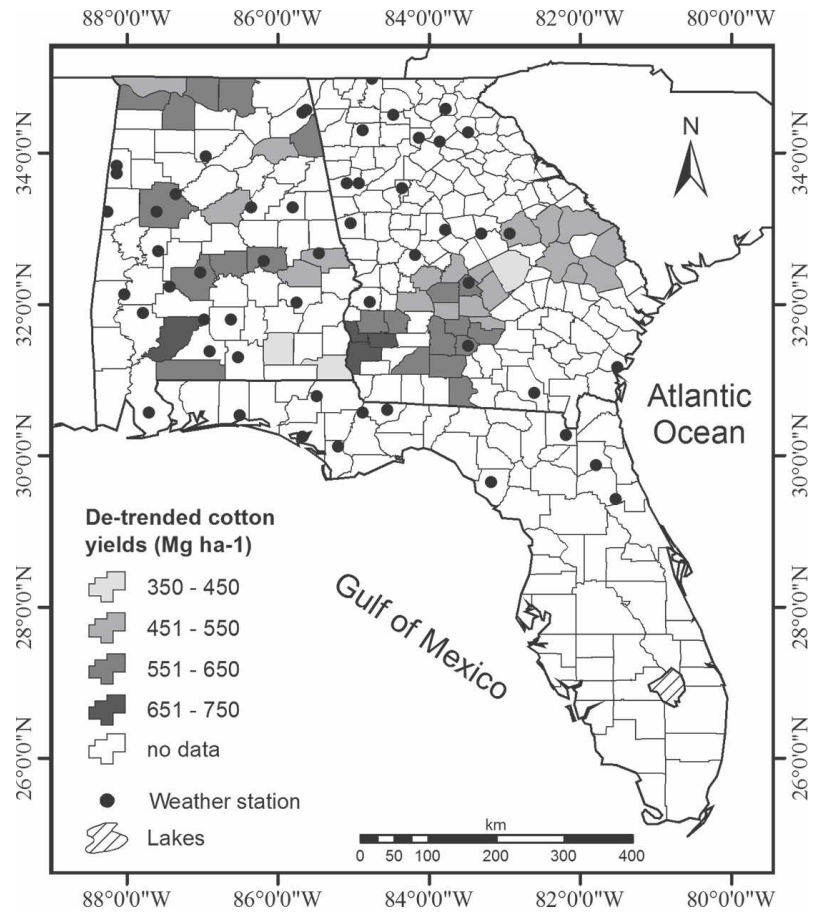

FIG. 2. Southeast United States showing locations of the 53 weather stations and the 48 counties with the average detrended cotton yields used in this study.

east. The main question addressed in this paper is whether a GCM, forced with SSTs, can be used to forecast rainfall and cotton yields. Specific objectives are to (i) evaluate the influence of regional atmospheric patterns on local rainfall and cotton yields, and (ii) evaluate the potential use of a GCM, ECHAM version 4.5, for estimating those regional atmospheric patterns and associated variability in cotton yields at a county scale in the Southeast.

\section{Methods}

\section{a. Data}

\section{1) CotTon Yield}

From 1970 through 2004, the National Agricultural Statistics Service (http://www.nass.usda.gov/) of the U.S. Department of Agriculture reported 211 counties in the states of Alabama (67), Florida (16), and Georgia (128) that produced cotton. From this database, cotton yield data from 48 counties with significant cotton production area (35-yr average ranging from 1500 to 22000 ha) from Alabama and Georgia were selected (Fig. 2). Lack of distinction in the production records between irrigated and rain-fed areas is a source of uncertainty, as irrigation makes the crop less sensitive to seasonal variability in rainfall.
Many nonclimatic factors influence cotton yield trends, including changes in varieties, technology (e.g., shifts between rainfed and irrigated production), soil quality, and market influences on input use and intensity of production. Analysis of cotton time series data must first account for such trends. We assumed that climatic influences on cotton yield generally occur at a higher frequency than nonclimatic influences. We used a low-pass spectral smoothing filter (Press et al. 1989) that removed a linear trend, applied a Fourier transformation, removed low-frequency variations, and then applied the inverse Fourier transformation and linear trend to obtain annual yield residuals (Fig. 3). Although the choice of smoothing period is subjective, we used a 10 -yr smoothing period based on unpublished experience with many crop datasets, thus avoiding removal of annual fluctuations in yield associated with climate variability. Cotton yield residuals were calculated as

$$
y_{\text {residual }}=\frac{y_{\text {observed }}}{y_{\text {trend }}}-1 .
$$

\section{2) Climate}

This study used three climate datasets: daily rainfall from 53 weather stations (Fig. 2) in the Southeast (National Climatic Data Center; http://www.ncdc. noaa.gov/oa/ncdc.html), monthly reanalysis data $\left(2.5^{\circ} \times\right.$ $2.5^{\circ}$ resolution) of mean surface temperature and wind fields at 850 and $200 \mathrm{hPa}$ (Kalnay et al. 1996), and monthly ECHAM retrospective simulation data $\left(\sim 2.8^{\circ} \times\right.$ $2.8^{\circ}$ resolution) for the same climate variables (Roeckner et al. 1996). All data corresponded to the period from April to September, which covers most of the cotton growing season in the Southeast. The retrospective simulation data from ECHAM 4.5 for this period was obtained during February-March of each year. The reanalysis and ECHAM 4.5 data were obtained from the International Research Institute for Climate and Society (http://iridl.ldeo.columbia.edu/).

Initial conditions in ECHAM 4.5 were sets of selfconsistent model fields that came from integrations of so-called atmospheric assimilation initial states, which are a combination of model data (D. DeWitt, IRI, 2006, personal communication). The average of an ensemble of 24 model integrations was used. For these integrations the model initial conditions were generated slightly differently for two sets of members: (i) members 1 to 8 were run by perturbing the initial atmospheric state and then spinning up the model for about six years to equilibrate the land surface model soil moisture; and (ii) members 9 to 24 were run using data from one of the previous realizations after adding atmospheric noise at about December 1949 to allow the 


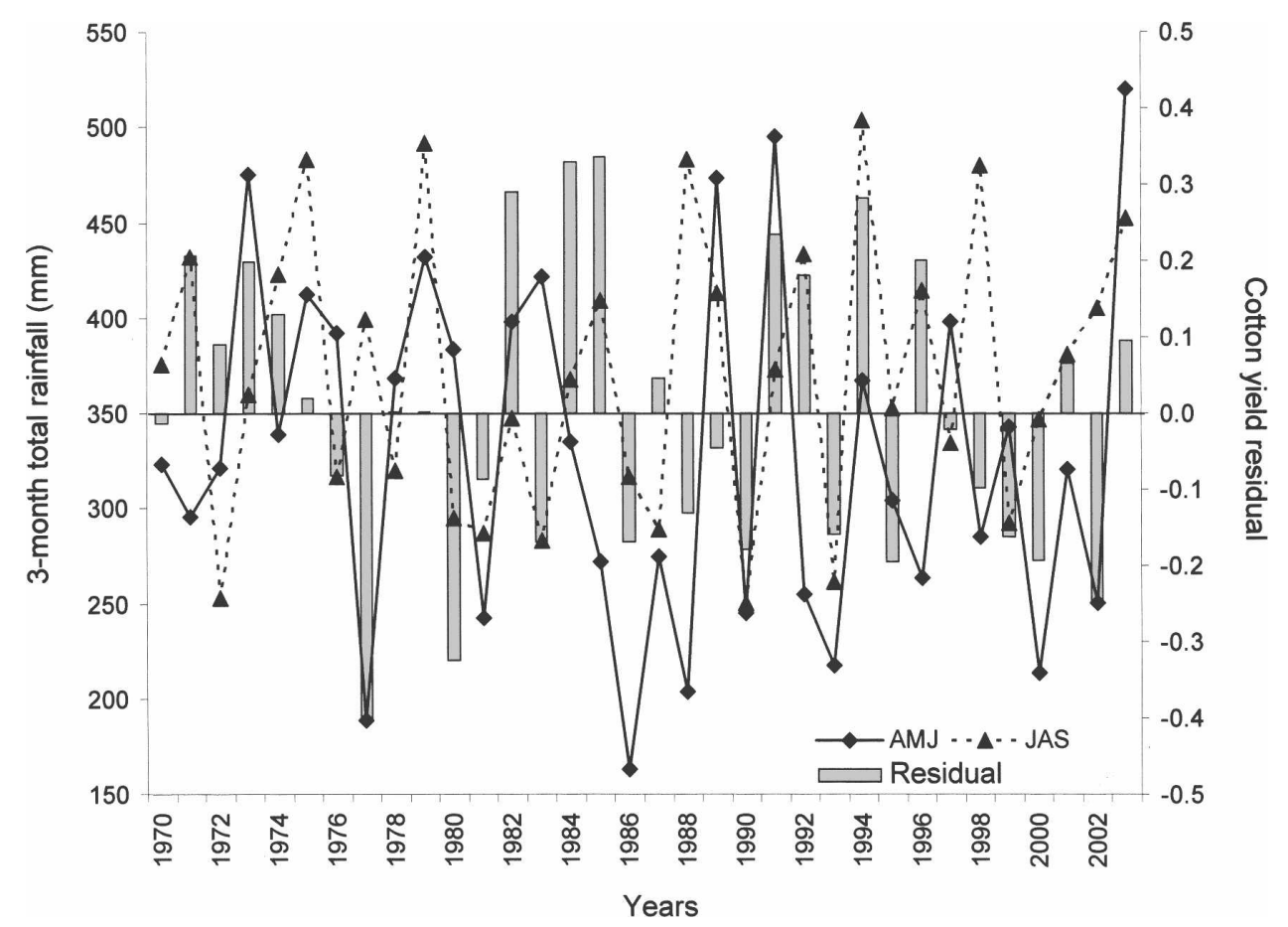

FIG. 3. Annual variability in cotton yield residuals (gray bars) averaged over all counties and annual variability of rainfall amounts averaged across all weather stations: total rainfall in April, May, and June (AMJ); and total rainfall in July, August, and September (JAS). Pearson correlation between cotton yield residuals and April, May, and June rainfall was 0.3561, significant at the 0.05 probability level. Pearson correlation between cotton yield residuals and July, August, and September rainfall was 0.32 and not significant.

models to diverge before January 1950, at which time their retrospective predictions started. These simulations are not predictions because they used SST observations after the fact instead of predicted SSTs. They represent an upper bound on forecast skill since we can never achieve perfect SST forecasts.

The period from 1970 through 2004 was used in this study to avoid long-term trends in rainfall detected in the Florida Panhandle, southeastern Alabama, and part of southwestern Georgia during the convective rainy season (Baigorria et al. 2007a). Monthly rainfall totals for each weather station were calculated from daily values. The yearly April-June and July-September allweather-station average is shown in Fig. 3.

\section{3) SUMMARIZING DATA BY PRINCIPAL COMPONENTS}

Principal component (PC) analysis is an effective way of summarizing correlated, multivariate spatial data. PCs are orthogonal linear transformations of a multivariate dataset. PCs were computed in our study in a sequence that successively minimizes the residual variance remaining after removing higher-order PCs. Using this approach, the first PC explained the greatest portion of temporal variance, and therefore captured the dominant mode of the interannual variability. The transformation matrix consists of eigenvectors of the correlation matrix, where the sum of the squared yearly weights is 1 (Wilks 2006; Hair et al. 1998). Calculating PCs from the correlation rather than covariance matrix avoids the tendency for the first few eigenvectors to give the highest weights to locations having the largest variances (Wilks 2006). The first principal component (PC1) was used to spatially aggregate the time series of cotton yields from the 48 counties. Similarly, using the time series of observed rainfall from the 53 stations in the study region, a PC1 was computed that spatially aggregates rainfall. Each PC had 35 weighted values corresponding to years 1970 through 2004. These time series of PC weights represent the filtered interannual variability of the spatially aggregated cotton yields and rainfall, capturing most of the spatial variance of the original variables. For gridded atmospheric variables in the reanalysis and GCM datasets, up to three principal components were used. Similar to cotton yield and rainfall, each of the PCs computed from these two datasets contained 35 weighted values. 


\section{b. Association between cotton yield and climate}

Simple correlations between the first PCs of observed monthly rainfall during the April to October growing season and county cotton yield residuals were evaluated. Spatial correlation patterns between regional climate variables and spatially aggregated cotton yield residuals were then examined. Monthly variables from the reanalysis data for each grid cell were averaged for April to June and for July to September, the early and late portions of the growing season. The growing season was split for three reasons. First, weather conditions that favor early vegetative growth are different than those that favor flowering, boll formation, and maturation. Second, unpublished diagnostics (A. Barnston, IRI, 2005, personal communication) indicate that the ENSO influence on rainfall in the region reverses between the two periods. Finally, aggregating climate data into 3-month periods reduces the risk of spurious relationships and artificial skill. Correlations between PC1 of cotton yield residuals and each grid cell of the reanalysis climate variables were examined for spatial patterns that might suggest causal mechanisms.

Because PC1 of cotton yield residuals was significantly correlated with PC1s of wind fields in the upper troposphere $(200 \mathrm{hPa})$ and surface temperatures, further analyses focused on these two variables. Wind fields $(200 \mathrm{hPa})$ and surface temperatures were respectively averaged for the five detrended highest cotton yield years $(1982,1984,1985,1991$, and 1994) and the five lowest yield years (1977, 1980, 1990, 2000, and 2002). These composites were used to identify major differences in climate patterns associated with large yield differences. The 5 -yr sample size $(29 \%$ of the available period) was arbitrary. However the sample was large enough to identify pattern repetitions and small enough to focus only on the extreme events. To produce anomaly grids, climatological averages were subtracted from the eight composites: April-June and July-September winds and temperatures corresponding to the highest- and lowest-yielding years.

After identifying circulation patterns, initial analysis of the PCs of upper-troposphere wind and surface temperature for April-June and July-September identified the first and third PCs of 200-hPa meridional winds and the first PC of surface temperatures for July-September as the best predictors of the first PC of cotton yield residuals. Next, cotton yield residuals were estimated by canonical correlation analysis (CCA) using the 35-yr period. Also referred to as a double-barreled PC analysis, CCA is a statistical technique that identifies a sequence of pairs of patterns in two multivariate datasets, and build sets of transformed variables by projecting the original data onto these patterns (Wilks 2006).

PCs of the regional temperature and circulation fields from reanalysis data were used to estimate the PC1 of cotton and county yield residuals by leave-oneout cross-validation CCA using the leading CCA mode (Efron and Gong 1983; Efron and Tibshirani 1993; Krzanowski 1987). Two jackknife validation analyses (Efron and Gong 1983; Gong 1986) were performed to confirm the reliability of the leave-one-out crossvalidation procedure. These jackknife validation analyses used $60 \%$ and $70 \%$ of the data for calibration whereas the remaining $40 \%$ and $30 \%$, respectively, were used for validation.

After determining that correlation between yield residuals and rainfall from a weather station was strongest in July, we used the same CCA procedure to investigate the relationship between local station precipitation and regional atmospheric circulation patterns. Composite grids of upper-tropospheric wind and surface temperature anomalies for the five wettest (1973, 1979, 1989, 1991, and 2003 for April-June; 1969, 1975, 1979, 1988, and 1994 for July-September) and five driest years (1977, 1986, 1988, 1993, and 2000 for AprilJune; 1972, 1981, 1983, 1990, and 1993 for July-September) were prepared, just as we did for the years with the highest and lowest cotton yields.

\section{c. Assessing potential cotton yield predictability}

After analyzing the association between cotton yields and regional atmospheric circulation patterns described above, the same CCA procedures were used with GCM outputs, instead of reanalysis data, to evaluate the potential predictability of cotton yield residuals. To do this, monthly retrospective simulations of meridional winds at $200 \mathrm{hPa}$ and surface temperatures during JulySeptember for the same 35-yr period were taken from ECHAM version 4.5 results. Cotton yield residuals were estimated by CCA. PCs of the regional temperature and circulation fields from ECHAM 4.5 using leave-one-out cross-validation analysis (Efron and Gong 1983; Efron and Tibshirani 1993; Krzanowski 1987) were used as predictors.

\section{d. Analysis of predictability}

Analyses of predictability were performed at each county by comparing the yearly observed cotton yield residuals with both yearly estimated cotton yield residuals (calculated by using reanalysis data and ECHAM 4.5 data). Predictability measures based on continuous predictands were Pearson's correlation $(R)$, Spearman's correlation $\left(R_{\text {rank }}\right)$, mean-square error 
(MSE), and a goodness-of-fit index (GFI) defined as the simple average of $R$ across all counties. Measures based on categorical predictands were the hit score and hit skill score (Murphy 1993).

The hit score is defined as the percentage of times the estimated quantile category corresponds with the observed quantile category [Eq. (2)]. The hit skill score is the percentage of times that the estimates fall within the correct quantile, beyond that expected by chance based on climatology [Eq. (3)]:

$$
\begin{aligned}
\text { hit score }= & \frac{\text { No. correct forecasts }}{\text { No. forecasts }} \times 100 \% \\
\text { hit skill score }= & \frac{\text { No. correct }- \text { No. expected correct }}{\text { No. forecasts }- \text { No. expected correct }} \\
& \times 100 \% .
\end{aligned}
$$

Hit score and hit skill score were computed using three categorical classes (terciles) and also using two categorical classes. The category boundaries for terciles were at the 33.3 and 66.6 percentiles to create belownormal, normal, and above-normal categories. The boundary for two categories was the average across the 35 -yr period. The hit skill score ranges between $-100 \%$ (total lack of predictability beyond chance) and $100 \%$ (maximum predictability).

\section{Results and discussion}

\section{a. Association between cotton yield and climate}

The highest and lowest detrended cotton yields did not occur in the wettest and driest years (Fig. 3). The regional atmospheric variables having the highest correlations with cotton yields were meridional winds at $200 \mathrm{hPa}$ and surface temperatures. Figure 4 shows the spatial pattern of correlations between regional climatic variables and detrended cotton yields. Positive values of meridional winds at $200 \mathrm{hPa}$ (southern winds) were favorable to crop yields, while negative values of meridional winds at the same altitude (northern winds) were unfavorable (Fig. 4a). Changes in wind direction were related in part to the location of the western sector of the North Atlantic Subtropical Anticyclone (Davis et al. 1997; Sahsamanoglou 1990; Klein 1957). Low temperatures were favorable to crop yield, while high temperatures were unfavorable (Fig. 4b).

Figure 5a shows wind anomalies in the upper troposphere and SST during the highest and lowest cotton yield years. In the highest cotton yield years, observed wind anomalies were from east to west in April-June, while in the lowest-yielding years, wind anomalies were from west to east. During July-September, wind anomalies changed from southeast during the highest cotton yield years, to northeast for the lowest cotton yield years, which is consistent with the previous correlations (Fig. 4a).

Temperature and humidity from where the winds came also help us characterize the relationships between regional climate patterns and cotton yields. During July-September, wind anomalies during the highest cotton yield years came from lower-than-normal SSTs in the Gulf of Mexico and the nearby Atlantic Ocean coast (Fig. 6). During the lowest cotton yield years, wind anomalies came from higher-than-normal SSTs in the Gulf of Mexico near the surface $(850 \mathrm{hPa})$, and from the Great Lakes and the northern Atlantic Ocean coast in the upper troposphere $(200 \mathrm{hPa})$.

From July to September, rainfall in the study area is dominated by convection triggered by warm ground surfaces and thus has low spatial correlation (Baigorria et al. 2007a). Depending on temperature and humidity of the air mass, advection can either intensify or decrease convective rainfall. In the highest cotton yield years, air with lower-than-normal temperatures carried from the Gulf of Mexico and the nearby Atlantic Ocean coast has higher density than normal, resulting in increased subsidence of the upper air mass. This subsidence is unfavorable to convective cloud formation. During the lowest cotton yield years, air with warmerthan-normal temperatures from the Gulf of Mexico near the surface and from the Great Lakes and northern Atlantic Ocean coast in the upper troposphere has lower density than normal, increasing the convective activity in the study area. Although low altitude advection is from a water source in both cases, differences in airmass temperature result in different absolute humidity. This means that during the lowest cotton yield years, warmer-than-normal conditions are associated with increased water available for condensation in the canopy of the crop. This difference in humidity influences two important cotton diseases in this region, hardlock and boll rot. These fungal diseases infect cotton during the six- to eight-week flowering window and during boll maturity, which occurs around July to September in the Southeast. The inverse relationship between surface temperature and the PC1 of cotton yield (Fig. 4b) supports this hypothesis.

For $74 \%$ of the counties, station rainfall showed the strongest association with cotton yields $(\mathrm{GFI}=0.485)$ in July (Table 1). Fewer counties showed significant yield correlations with rainfall in August or September, maybe due to later planting dates. Because irrigation usually decreases the dependency of crops on rainfall, we suspect that the five counties with nonsignificant correlations between cotton yields and rainfall in any month may have had a high percentage of fields under 

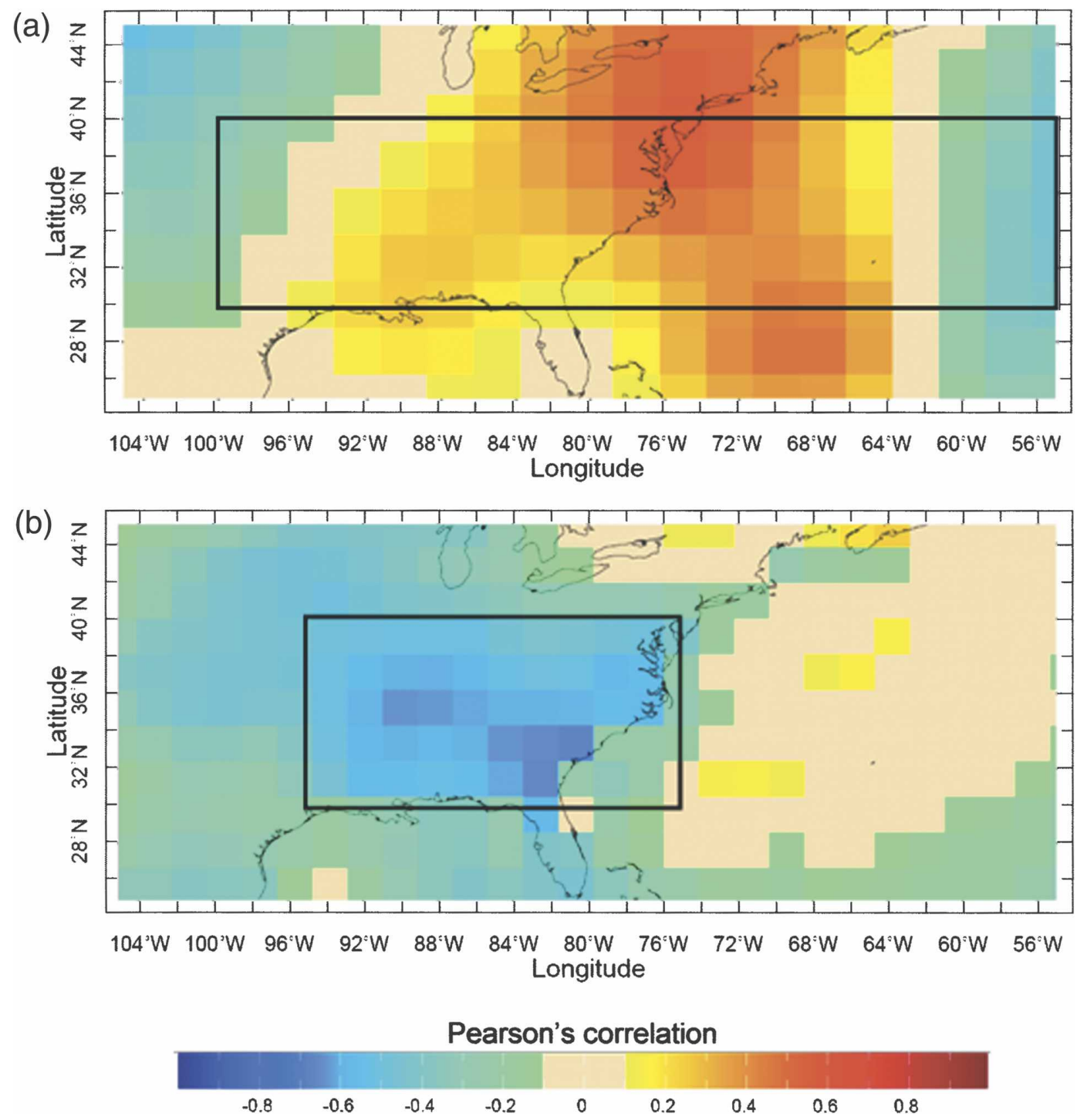

FIG. 4. Correlation maps between the PC1 of observed cotton yield residuals and July-September (a) meridional winds at $200 \mathrm{hPa}$ and (b) surface temperature. Boxes indicate the geographical domain of each predictor.

irrigation. In the Southeast, cotton is usually planted between early April and late May. Early planting dates ensure enough rainfall during the cropping season, but with higher risk of diseases during the rainy season of July-September, especially during highly active hurricane seasons.

Among all regional atmospheric variables that we considered, meridional winds at $850 \mathrm{hPa}$ showed the highest correlations with July rainfall. The area shown in Fig. 7 was used in the CCA for estimating July rainfall.

During the five years with highest July rainfall, observed wind anomalies came from the southwest (Fig.
$5 b)$. During the years with lowest July rainfall, wind anomalies came from the northeast for both April-June and July-September. These patterns are different from the ones shown during the highest and lowest years of cotton yields (Fig. 5a). The relationship between wind direction and rainfall regimes agree with the annual migration of the subtropical anticyclone over the North Atlantic (Stahle and Cleaveland 1992; Davis et al. 1997). Analyses (not shown) revealed that cotton yields were not explained by $850-\mathrm{hPa}$ meridional winds. We therefore selected meridional winds at $200 \mathrm{hPa}$ and surface temperatures as atmospheric predictors of cotton yields. 
(a)

Highest-yielding

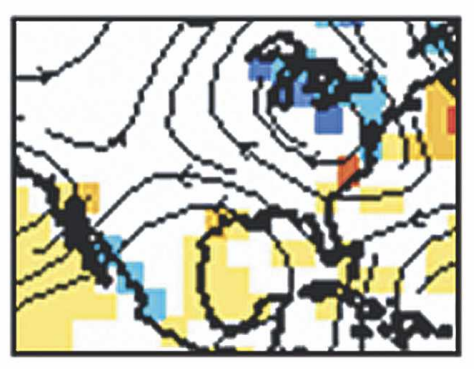

AMJ

JAS

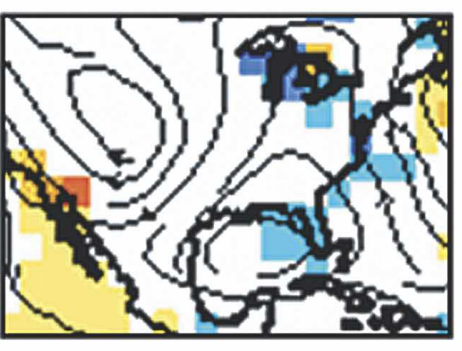

(b)

AMJ

Wettest

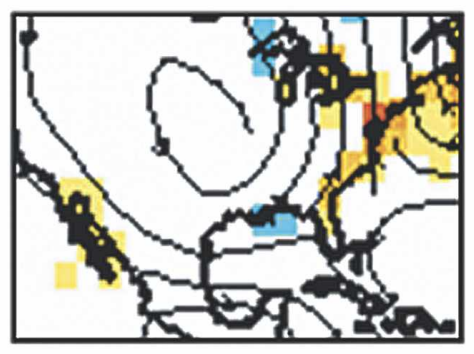

JAS

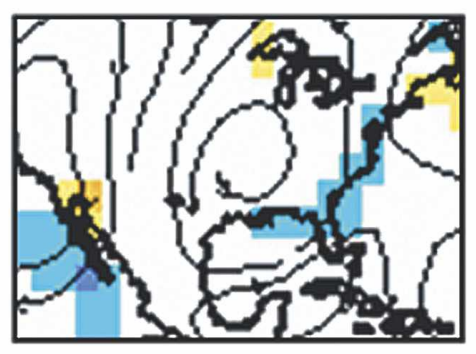

Lowest-yielding
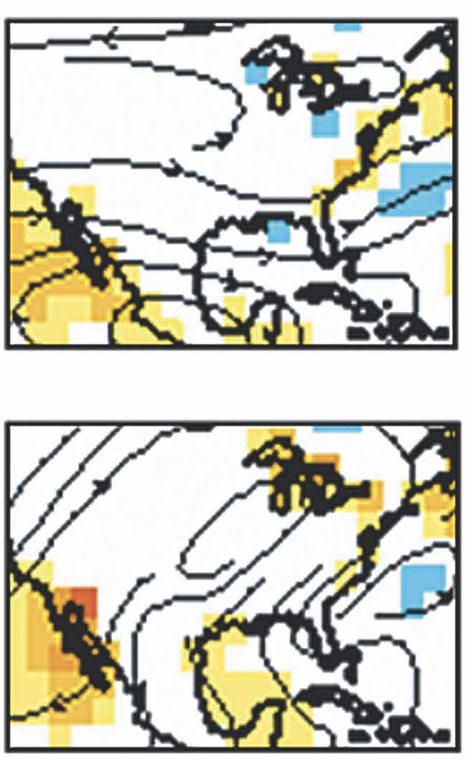

Driest
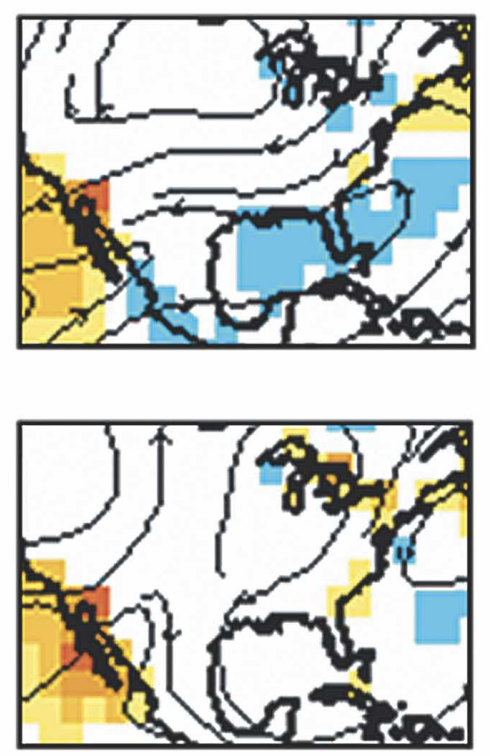

SST anomalies $\left({ }^{\circ} \mathrm{C}\right)$

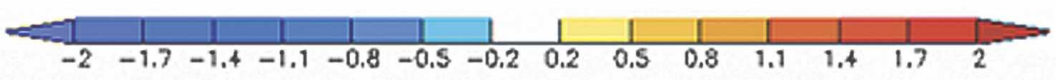

FIG. 5. Anomalies of SST (colors) and wind fields (lines with arrows) in the upper troposphere (200 $\mathrm{hPa}$ ). Observed (reanalysis) values during the periods April-June and July-September (a) for the (left) five highest and (right) five lowest years of cotton yields and (b) for the (left) five wettest and (right) five driest years. 


\section{July - August - September}

\section{Highest cotton yield}

\section{Lowest cotton yield}

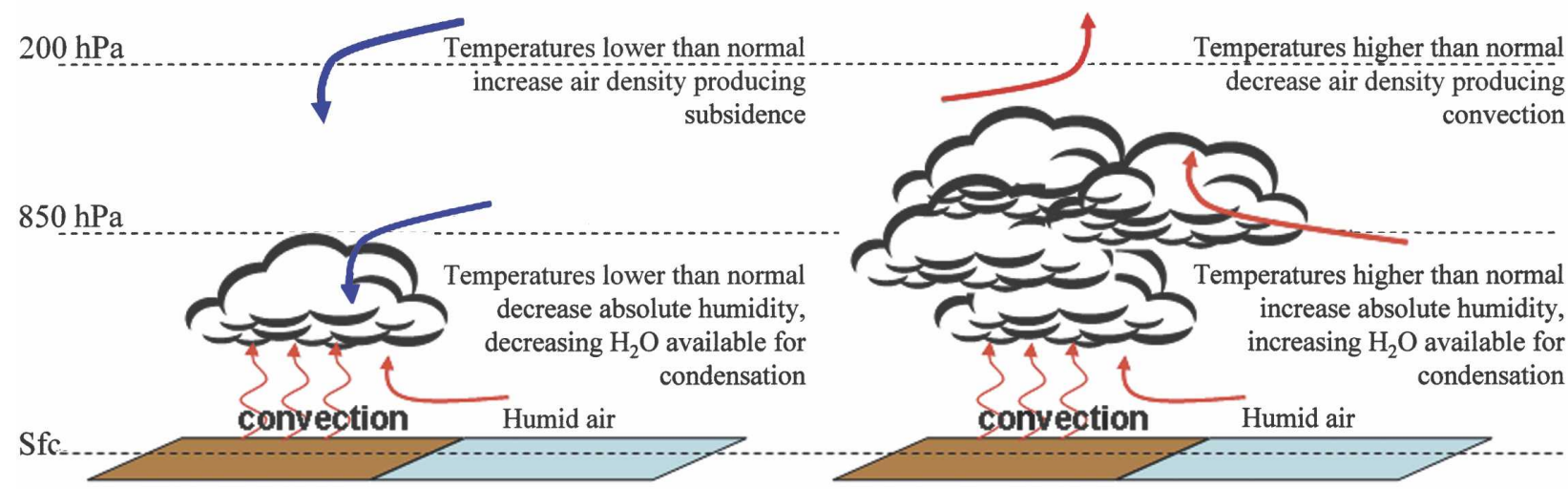

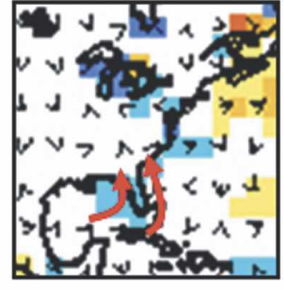

$850 \mathrm{hPa}$

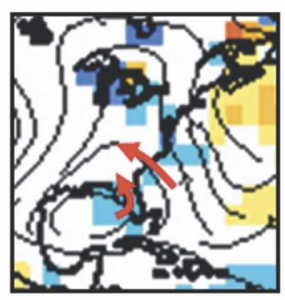

$200 \mathrm{hPa}$

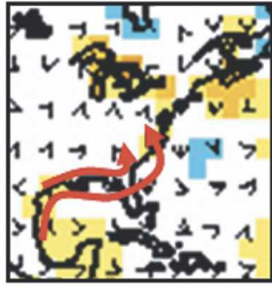

$850 \mathrm{hPa}$

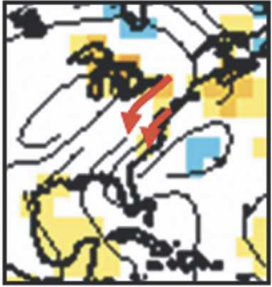

$200 \mathrm{hPa}$

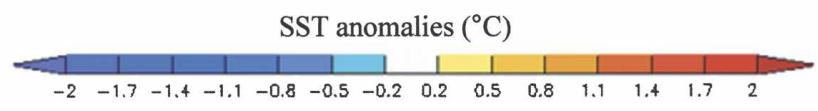

FIG. 6. Effect of wind (black arrowheads and lines with arrows) and SST anomalies (colors) on cotton yields. Wind field anomalies at 850 and $200 \mathrm{hPa}$, and SST anomalies during the (left) five highest and (right) five lowest years of cotton yields. (bottom row) Red arrows emphasize the wind direction.

\section{b. Potential cotton yield predictability}

About $47 \%$ of the interannual variability of the cotton yield PC1 was explained by PCs of the regional temperature and circulation fields when using leaveone-out cross-validation analysis. Similar estimates were obtained using the jackknife validation procedure. The jackknife procedure explained about $56 \%$ and $53 \%$ of the interannual variability using $60 \%$ and $70 \%$ of the data for calibrations, respectively. The leave-one-out cross-validation and both jackknife validation results were significant at the 0.01 probability level.

Figure 8 compares detrended cotton yields with cross-validated estimates based on upper-troposphere wind and surface temperature fields from reanalysis and from ECHAM 4.5 data, for averages across counties, and for the best- and the worst-estimated counties. Reanalysis data provided reasonable predictability ( $p$ $<0.01$ ) of average yields across counties (Fig. 8a) and for the best-estimated county (Fig. 8b). The one notable exception, 1977, was one of the most severe droughts in the last $50 \mathrm{yr}$ in the southeast United States. The average cotton yield was relatively low (ranked 46 th out of 48 counties) in the best-estimated county

TABLE 1. GFI of the cross-validated yield residual predictions vs observed yield residuals over 53 counties using monthly rainfall as the predictor.

\begin{tabular}{lcccc}
\hline & & \multicolumn{3}{c}{ Percentage of counties significant at } \\
\cline { 3 - 5 } \multicolumn{1}{c}{ Months } & GFI & $\alpha=0.01$ & $\alpha=0.05$ & NS* \\
\hline April & -0.101 & 0 & 0 & 100 \\
May & -0.117 & 0 & 0 & 100 \\
June & -0.042 & 0 & 0 & 100 \\
July & 0.485 & 69 & 15 & 16 \\
August & 0.132 & 2 & 11 & 87 \\
September & 0.098 & 2 & 6 & 92 \\
October & 0.042 & 0 & 0 & 100 \\
\hline
\end{tabular}

$* \mathrm{NS}=$ not significant 

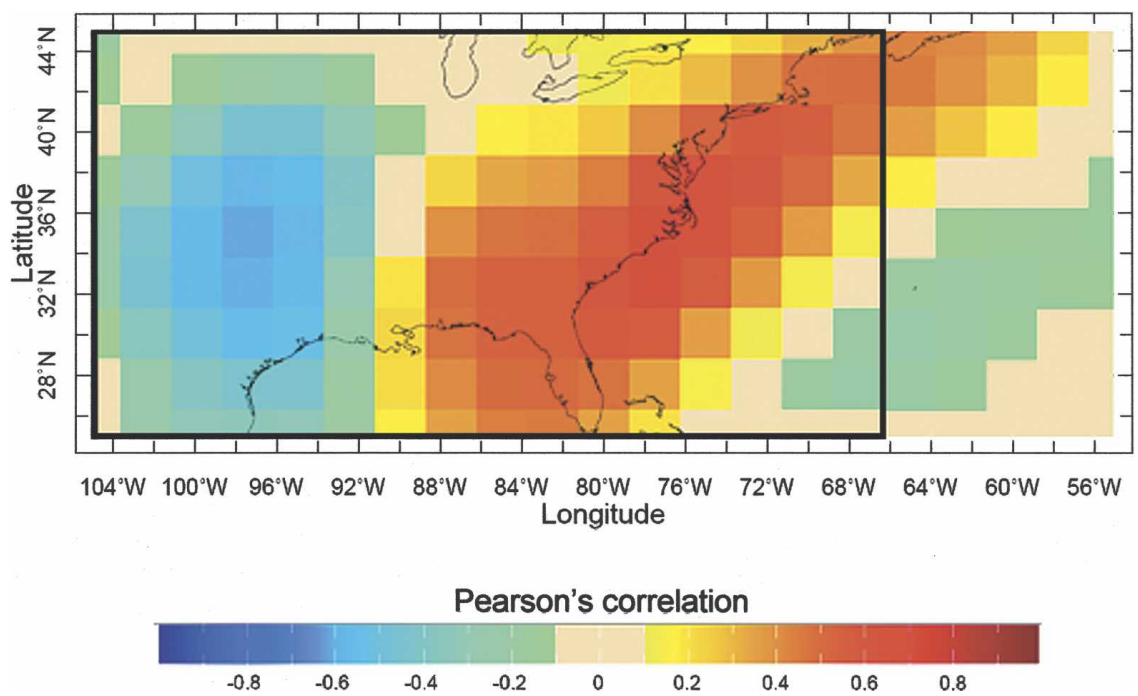

FIG. 7. Correlations between the PC1 of the observed July rainfall and July-September meridional winds at $850 \mathrm{hPa}$. Box indicates the geographical domain of the predictor.
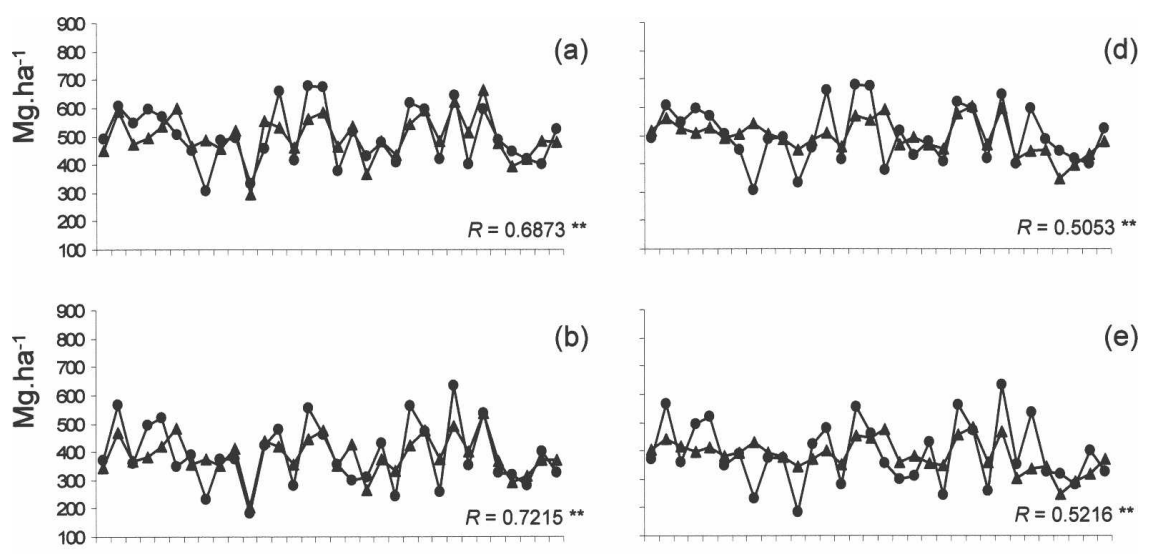

(b)
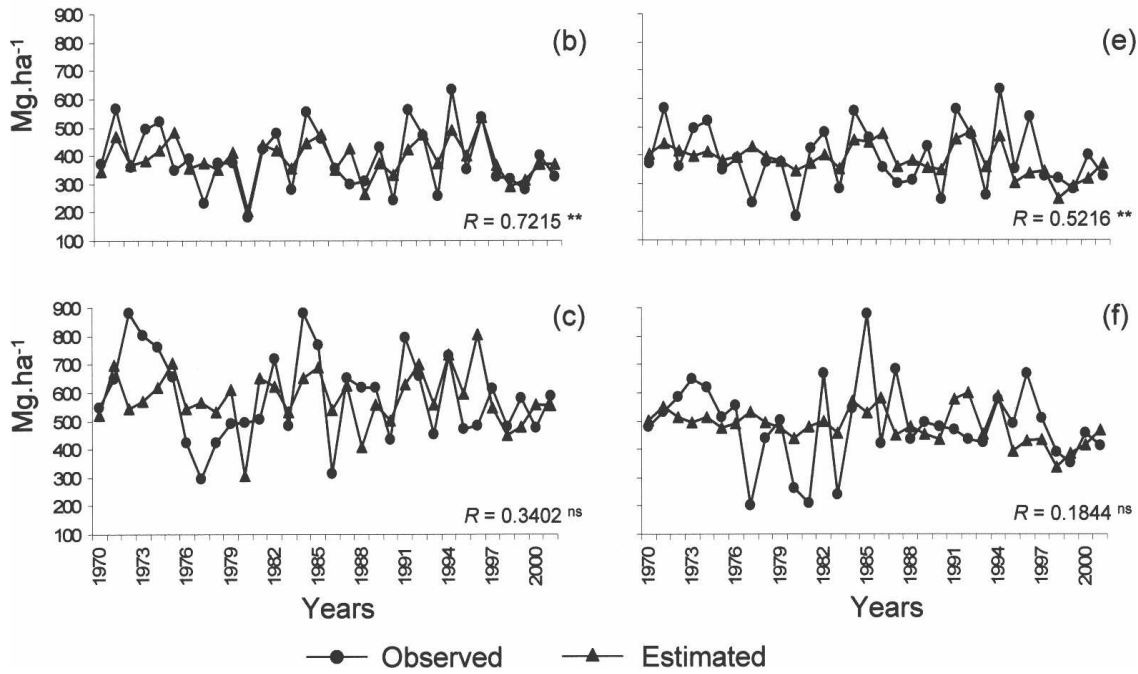

FIG. 8. Comparison of annual variability in observed detrended yield with estimated detrended yield using predictors from reanalysis data (a) mean over all counties, (b) bestestimated county (Laurens, GA), and (c) worst-estimated county (Clay, GA), and from the ECHAM 4.5 retrospective simulation (d) mean over all counties, (e) best-estimated county (Laurens), and (f) worst-estimated county (Sumter, GA). The Pearson correlation $R$ is in each panel with two asterisks denoting significance at the 0.01 probability level and NS denoting nonsignificance. 
TABLE 2. Validation statistics based on cross validation by county. Cotton yield residuals were estimated using meridional winds in the upper troposphere and surface temperature from the reanalysis dataset.

\begin{tabular}{|c|c|c|c|c|c|c|c|}
\hline \multirow[b]{2}{*}{ County (state) } & \multirow[b]{2}{*}{$R$} & \multirow[b]{2}{*}{$R_{\mathrm{rank}}$} & \multirow[b]{2}{*}{ MSE } & \multicolumn{2}{|c|}{ Based on terciles } & \multicolumn{2}{|c|}{ Based on average } \\
\hline & & & & Hit score $(\%)$ & Hit skill score $(\%)$ & Hit score $(\%)$ & Hit skill score (\%) \\
\hline Laurens (GA) & $0.7215^{\mathrm{a}}$ & 0.6620 & 0.04 & 68.8 & 53.1 & 78.1 & 46.2 \\
\hline Bleckley (GA) & $0.7211^{\mathrm{a}}$ & 0.6671 & 0.04 & 68.8 & 53.1 & 87.5 & 66.7 \\
\hline Dooly (GA) & $0.6911^{\mathrm{a}}$ & 0.6811 & 0.06 & 59.4 & 39.1 & 78.1 & 53.3 \\
\hline Burke (GA) & $0.6772^{\mathrm{a}}$ & 0.7155 & 0.06 & 68.8 & 53.1 & 78.1 & 46.2 \\
\hline Macon (GA) & $0.6640^{\mathrm{a}}$ & 0.6210 & 0.05 & 56.3 & 34.4 & 78.1 & 58.8 \\
\hline Jefferson (GA) & $0.6287^{\mathrm{a}}$ & 0.6111 & 0.06 & 68.8 & 53.1 & 75.0 & 50.0 \\
\hline Dodge (GA) & $0.6258^{\mathrm{a}}$ & 0.6081 & 0.04 & 59.4 & 39.1 & 71.9 & 40.0 \\
\hline Emanuel (GA) & $0.6118^{\mathrm{a}}$ & 0.5777 & 0.05 & 53.1 & 29.7 & 71.9 & 47.1 \\
\hline Crisp (GA) & $0.5977^{\mathrm{a}}$ & 0.5976 & 0.04 & 46.9 & 20.3 & 87.5 & 71.4 \\
\hline Terrell (GA) & $0.5804^{\mathrm{a}}$ & 0.6525 & 0.03 & 46.9 & 20.3 & 81.3 & 62.5 \\
\hline Pulaski (GA) & $0.5784^{\mathrm{a}}$ & 0.5770 & 0.06 & 65.6 & 48.4 & 68.8 & 44.4 \\
\hline Colquitt (GA) & $0.5778^{\mathrm{a}}$ & 0.6515 & 0.03 & 62.5 & 43.8 & 84.4 & 73.7 \\
\hline Worth (GA) & $0.5753^{\mathrm{a}}$ & 0.6057 & 0.03 & 56.3 & 34.4 & 84.4 & 61.5 \\
\hline Washington (GA) & $0.5746^{\mathrm{a}}$ & 0.5832 & 0.07 & 56.3 & 34.4 & 81.3 & 50.0 \\
\hline Coffee (AL) & $0.5740^{\mathrm{a}}$ & 0.6246 & 0.04 & 56.3 & 34.4 & 84.4 & 70.6 \\
\hline Screven (GA) & $0.5712^{\mathrm{a}}$ & 0.5701 & 0.05 & 50.0 & 25.0 & 68.8 & 28.6 \\
\hline Houston (GA) & $0.5645^{\mathrm{a}}$ & 0.6170 & 0.06 & 62.5 & 43.8 & 75.0 & 42.9 \\
\hline Madison (AL) & $0.5544^{\mathrm{a}}$ & 0.5355 & 0.04 & 53.1 & 29.7 & 71.9 & 40.0 \\
\hline Turner (GA) & $0.5309^{\mathrm{a}}$ & 0.5843 & 0.06 & 56.3 & 34.4 & 81.3 & 57.1 \\
\hline Tift (GA) & $0.5209^{\mathrm{a}}$ & 0.5520 & 0.03 & 56.3 & 34.4 & 78.1 & 53.3 \\
\hline Lauderdale (AL) & $0.5168^{\mathrm{a}}$ & 0.5312 & 0.04 & 56.3 & 34.4 & 75.0 & 38.5 \\
\hline Monroe (AL) & $0.5082^{\mathrm{a}}$ & 0.5091 & 0.03 & 50.0 & 25.0 & 75.0 & 42.9 \\
\hline Wilcox (GA) & $0.5000^{\mathrm{a}}$ & 0.5274 & 0.05 & 53.1 & 29.7 & 78.1 & 46.2 \\
\hline Etowah (AL) & $0.4993^{\mathrm{a}}$ & 0.4454 & 0.08 & 56.3 & 34.4 & 68.8 & 37.5 \\
\hline Cherokee (AL) & $0.4989^{\mathrm{a}}$ & 0.4600 & 0.08 & 53.1 & 29.7 & 65.6 & 35.3 \\
\hline Randolph (GA) & $0.4977^{\mathrm{a}}$ & 0.6052 & 0.05 & 50.0 & 25.0 & 84.4 & 66.7 \\
\hline Candler (GA) & $0.4921^{\mathrm{a}}$ & 0.4366 & 0.06 & 56.3 & 34.4 & 62.5 & 25.0 \\
\hline Limestone (AL) & $0.4905^{\mathrm{a}}$ & 0.4952 & 0.05 & 50.0 & 25.0 & 68.8 & 28.6 \\
\hline Colbert (AL) & $0.4777^{\mathrm{a}}$ & 0.5029 & 0.05 & 59.4 & 39.1 & 75.0 & 42.9 \\
\hline Lee $(\mathrm{AL})$ & $0.4676^{\mathrm{a}}$ & 0.4312 & 0.04 & 46.9 & 20.3 & 65.6 & 15.4 \\
\hline Ben Hill (GA) & $0.4642^{\mathrm{a}}$ & 0.4446 & 0.06 & 46.9 & 20.3 & 78.1 & 53.3 \\
\hline Sumter (GA) & $0.4504^{\mathrm{a}}$ & 0.4967 & 0.07 & 50.0 & 25.0 & 75.0 & 50.0 \\
\hline Dallas (AL) & $0.4454^{\mathrm{b}}$ & 0.5239 & 0.04 & 50.0 & 25.0 & 65.6 & 35.3 \\
\hline Macon (AL) & $0.4378^{\mathrm{b}}$ & 0.3985 & 0.05 & 50.0 & 25.0 & 68.8 & 28.6 \\
\hline Lawrence (AL) & $0.4356^{\mathrm{b}}$ & 0.5209 & 0.05 & 56.3 & 34.4 & 65.6 & 15.4 \\
\hline Elmore (AL) & $0.4331^{\mathrm{b}}$ & 0.4257 & 0.05 & 37.5 & 6.3 & 65.6 & 35.3 \\
\hline Bulloch (GA) & $0.4240^{\mathrm{b}}$ & 0.4256 & 0.06 & 50.0 & 25.0 & 62.5 & 25.0 \\
\hline Mitchell (GA) & $0.4154^{\mathrm{b}}$ & 0.5242 & 0.04 & 56.3 & 34.4 & 59.4 & 27.8 \\
\hline Irwin (GA) & $0.4096^{\mathrm{b}}$ & 0.4787 & 0.05 & 50.0 & 25.0 & 68.8 & 44.4 \\
\hline Early (GA) & $0.3963^{\mathrm{b}}$ & 0.5221 & 0.04 & 43.8 & 15.6 & 75.0 & 50.0 \\
\hline Brooks (GA) & $0.3935^{\mathrm{b}}$ & 0.5326 & 0.02 & 43.8 & 15.6 & 78.1 & 58.8 \\
\hline Tuscaloosa (AL) & $0.3903^{\mathrm{b}}$ & 0.4725 & 0.04 & 46.9 & 20.3 & 78.1 & 53.3 \\
\hline Calhoun (GA) & $0.3811^{\mathrm{b}}$ & 0.4405 & 0.03 & 40.6 & 10.9 & 75.0 & 50.0 \\
\hline Escambia (AL) & $0.3717^{\mathrm{b}}$ & 0.3943 & 0.03 & 50.0 & 25.0 & 62.5 & 25.0 \\
\hline Houston (AL) & $0.3652^{\mathrm{b}}$ & 0.3756 & 0.07 & 43.8 & 15.6 & 68.8 & 23.1 \\
\hline Autauga (AL) & $0.3589^{\mathrm{b}}$ & 0.4501 & 0.05 & 53.1 & 29.7 & 75.0 & 50.0 \\
\hline Shelby (AL) & $0.3585^{\mathrm{b}}$ & 0.3966 & 0.04 & 43.8 & 15.6 & 65.6 & 35.3 \\
\hline Clay (GA) & $0.3402^{\mathrm{c}}$ & 0.4707 & 0.07 & 37.5 & 6.3 & 68.8 & 37.5 \\
\hline
\end{tabular}

${ }^{\text {a }}$ Significant at the 0.01 probability level.

${ }^{\mathrm{b}}$ Significant at the 0.05 probability level.

${ }^{\mathrm{c}}$ Not significant.

(Laurens, Georgia), while the highest-yielding county (Clay, Georgia) showed the weakest predictability from reanalysis variables. This is consistent with our speculation that climate-based yield predictability is weaker in counties with greater proportion of cultivated areas under irrigation, but data are not available to test this. Differences in soils, management or climate may also account for the differences in yields. There is a weak 
(a)

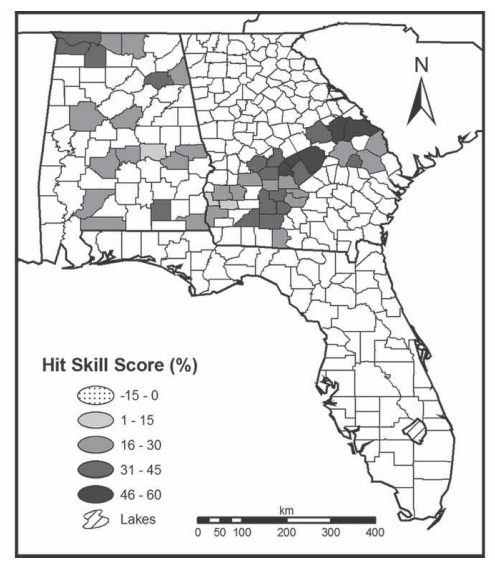

(b)

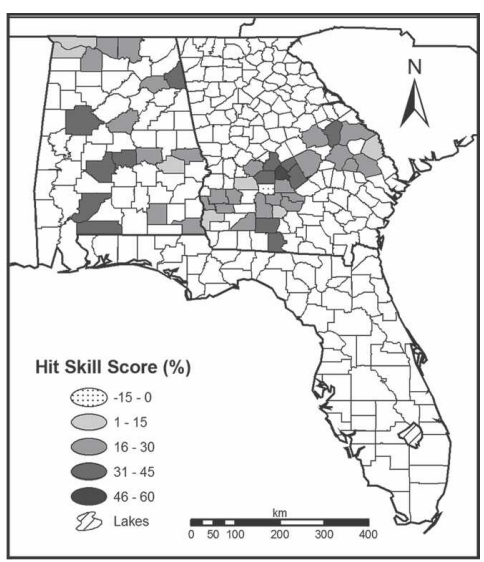

FIG. 9. Spatial distribution of forecast hit skill score, using (a) reanalysis climate predictors and (b) ECHAM 4.5 retrospective simulations made each year between February and April.

tendency for higher correlations to be associated with lower average yields.

Using reanalysis data, meridional winds in the upper atmosphere combined with surface temperatures during July-September explained up to $52 \%$ of the total yield variability in specific counties (Table 2). In 47 of the 48 counties, $R$ was statistically significant (67\% and $31 \%$ of the counties were statistically significant at $p=0.01$ and 0.05 , respectively). Values of $R$ and $R_{\text {rank }}$ were similar, suggesting that the climate drivers were not influenced seriously by extreme data (e.g., hurricanes). In all cases, cotton yield predictability as measured by hit skill scores was better than chance. The spatial distribution of a hit skill score based on terciles (Fig. 9) is likely related to the variations in irrigation or other management factors among counties.

Although rainfall in April and June was not a useful predictor of cotton yields, zonal (west-east) winds at $200 \mathrm{hPa}$ did explain part of the April rainfall variability in the Southeast (GFI $=0.309$ ), during the time when most of the summer crops are planted.

Yields averaged across counties also showed significant predictability $(p<0.01)$ from atmospheric fields simulated by ECHAM 4.5 (Fig. 8d). However, in absolute terms, the number of counties with significant predictability levels decreased. Based on the Pearson correlation, the percentage of counties with predictability significant at the 0.01 probability level decreased from $67 \%$ to when using reanalysis to $23 \%$ using the ECHAM 4.5 data. At the 0.05 probability level, the percentage of counties increased from $31 \%$ to $35 \%$ for the same comparison (Table 2 and 3). As expected, the predictability of yields from using GCM outputs was lower than that based on the reanalysis data. This is as a result of the uncertainties of the GCM predictions of the specific geographical domain and intensity of the atmospheric patterns.

Based on hit skill scores, predictability was still better than chance except in one county. The hit scores using terciles ranged between $69.7 \%$ (Pulaski, Georgia) and $30.3 \%$ (Crisp, Georgia) and between 54.5\% (Pulaski) and $-9.1 \%$ (Crisp) for the hit skill score (Table 3). Hit scores for predicting yields in two categories ranged from $81.3 \%$ (Dooly and Ben Hill, Georgia) to 53.6\% (Mitchell, Georgia), and the hit skill score ranged from $60.0 \%$ (Dooly and Ben Hill) to $7.7 \%$ (Lawrence and Lauderdale; Table 3).

Using ECHAM 4.5 data, we were unable to estimate the low yields observed in 1977, 1980, and 1986. Regional atmospheric variables from reanalysis data also did not estimate the low yield associated with the 1977 drought (Fig. 8). The correlation ranking of counties differed between estimations based on ECHAM 4.5 and estimations based on reanalysis (Tables 2 and 3). Predictability of cotton yields in individual counties tended to be weaker than that of the average yields across counties $(R=0.51)$, with correlations ranging from 0.52 in Laurens County to 0.18 in Sumter County, both in Georgia (see Figs. 8d,e,f). Observed yields in Sumter County showed lower mean and higher interannual variability than the all-county average.

Our ability to estimate cotton yields was not directly related to our ability to estimate rainfall amounts using reanalysis data. Comparisons between Figs. 9a and 10 show that while the best cotton yields estimates were in central and eastern Georgia (Fig. 9), the best July rainfall estimates were in central and eastern Alabama and northwestern Georgia (Fig. 10). Although meridional winds at $850 \mathrm{hPa}$ estimated July rainfall better than winds at $200 \mathrm{hPa}$, meridional winds 
TABLE 3. As in Table 2, except residuals were estimated using GCM simulations of meridional winds in the upper troposphere and surface temperature.

\begin{tabular}{|c|c|c|c|c|c|c|c|}
\hline \multirow[b]{2}{*}{ County (state) } & \multirow[b]{2}{*}{$R$} & \multirow[b]{2}{*}{$R_{\text {rank }}$} & \multirow[b]{2}{*}{ MSE } & \multicolumn{2}{|c|}{ Based on terciles } & \multicolumn{2}{|c|}{ Based on average } \\
\hline & & & & Hit score $(\%)$ & Hit skill score (\%) & Hit score $(\%)$ & Hit skill score $(\%)$ \\
\hline Laurence (GA) & $0.5216^{\mathrm{a}}$ & 0.5211 & 0.06 & 48.5 & 22.7 & 68.8 & 23.1 \\
\hline Autauga (AL) & $0.5143^{\mathrm{a}}$ & 0.5368 & 0.04 & 57.6 & 36.4 & 71.9 & 43.8 \\
\hline Dooly (GA) & $0.5034^{\mathrm{a}}$ & 0.4940 & 0.08 & 54.5 & 31.8 & 81.3 & 60.0 \\
\hline Dodge (GA) & $0.5004^{\mathrm{a}}$ & 0.5388 & 0.05 & 57.6 & 36.4 & 75.0 & 46.7 \\
\hline Bleckley (GA) & $0.4850^{\mathrm{a}}$ & 0.4463 & 0.06 & 54.5 & 31.8 & 71.9 & 25.0 \\
\hline Wilcox (GA) & $0.4722^{\mathrm{a}}$ & 0.4588 & 0.05 & 48.5 & 22.7 & 75.0 & 38.5 \\
\hline Dallas (AL) & $0.4611^{\mathrm{a}}$ & 0.4894 & 0.04 & 57.6 & 36.4 & 62.5 & 29.4 \\
\hline Emanuel (GA) & $0.4546^{\mathrm{a}}$ & 0.4475 & 0.07 & 48.5 & 22.7 & 68.8 & 41.2 \\
\hline Coffee (AL) & $0.4405^{\mathrm{a}}$ & 0.4592 & 0.06 & 48.5 & 22.7 & 59.4 & 23.5 \\
\hline Candler (GA) & $0.4374^{\mathrm{a}}$ & 0.4659 & 0.06 & 45.5 & 18.2 & 75.0 & 50.0 \\
\hline Monroe (AL) & $0.4301^{\mathrm{a}}$ & 0.4491 & 0.03 & 57.6 & 36.4 & 75.0 & 42.9 \\
\hline Ben Hill (GA) & $0.4265^{\mathrm{b}}$ & 0.4052 & 0.06 & 48.5 & 22.7 & 81.3 & 60.0 \\
\hline Macon (AL) & $0.4185^{\mathrm{b}}$ & 0.4586 & 0.05 & 42.4 & 13.6 & 78.1 & 50.0 \\
\hline Houston (GA) & $0.4077^{\mathrm{b}}$ & 0.4789 & 0.08 & 60.6 & 40.9 & 71.9 & 35.7 \\
\hline Washington (GA) & $0.4061^{\mathrm{b}}$ & 0.5007 & 0.08 & 48.5 & 22.7 & 71.9 & 25.0 \\
\hline Lee $(\mathrm{AL})$ & $0.3991^{\mathrm{b}}$ & 0.4287 & 0.04 & 45.5 & 18.2 & 68.8 & 23.1 \\
\hline Worth (GA) & $0.3947^{\mathrm{b}}$ & 0.4092 & 0.04 & 51.5 & 27.3 & 75.0 & 38.5 \\
\hline Macon (GA) & $0.3927^{\mathrm{b}}$ & 0.4050 & 0.07 & 48.5 & 22.7 & 68.8 & 41.2 \\
\hline Escambia (AL) & $0.3915^{\mathrm{b}}$ & 0.4139 & 0.03 & 54.5 & 31.8 & 68.8 & 37.5 \\
\hline Pulaski (GA) & $0.3862^{\mathrm{b}}$ & 0.4208 & 0.08 & 69.7 & 54.5 & 71.9 & 50.0 \\
\hline Madison (AL) & $0.3832^{\mathrm{b}}$ & 0.3475 & 0.05 & 48.5 & 22.7 & 62.5 & 20.0 \\
\hline Houston (AL) & $0.3780^{\mathrm{b}}$ & 0.4279 & 0.07 & 45.5 & 18.2 & 71.9 & 30.8 \\
\hline Clay (GA) & $0.3730^{\mathrm{b}}$ & 0.4134 & 0.06 & 48.5 & 22.7 & 65.6 & 31.3 \\
\hline Tuscaloosa (AL) & $0.3725^{\mathrm{b}}$ & 0.4362 & 0.04 & 57.6 & 36.4 & 68.8 & 33.3 \\
\hline Calhoun (GA) & $0.3715^{\mathrm{b}}$ & 0.4909 & 0.03 & 51.5 & 27.3 & 68.8 & 37.5 \\
\hline Colquitt (GA) & $0.3656^{\mathrm{b}}$ & 0.4359 & 0.04 & 54.5 & 31.8 & 62.5 & 36.8 \\
\hline Limestone (AL) & $0.3580^{\mathrm{b}}$ & 0.3707 & 0.06 & 48.5 & 22.7 & 65.6 & 21.4 \\
\hline Crisp (GA) & $0.3486^{\mathrm{b}}$ & 0.4195 & 0.06 & 30.3 & -9.1 & 71.9 & 35.7 \\
\hline Etowah (AL) & $0.3432^{\mathrm{c}}$ & 0.4037 & 0.09 & 51.5 & 27.3 & 65.6 & 31.3 \\
\hline Colbert (AL) & $0.3335^{\mathrm{c}}$ & 0.3650 & 0.06 & 42.4 & 13.6 & 65.6 & 21.4 \\
\hline Early (GA) & $0.3328^{c}$ & 0.3564 & 0.04 & 36.4 & 4.5 & 71.9 & 43.8 \\
\hline Brooks (GA) & $0.3279^{c}$ & 0.2670 & 0.02 & 54.5 & 31.8 & 56.3 & 17.6 \\
\hline Elmore (AL) & $0.3264^{\mathrm{c}}$ & 0.3642 & 0.06 & 48.5 & 22.7 & 68.8 & 41.2 \\
\hline Cherokee (AL) & $0.3196^{\mathrm{c}}$ & 0.3486 & 0.09 & 57.6 & 36.4 & 68.8 & 41.2 \\
\hline Tift (GA) & $0.3173^{c}$ & 0.3452 & 0.04 & 42.4 & 13.6 & 68.8 & 33.3 \\
\hline Turner (GA) & $0.3109^{c}$ & 0.3720 & 0.07 & 45.5 & 18.2 & 78.1 & 50.0 \\
\hline Bulloch (GA) & $0.2976^{\mathrm{c}}$ & 0.3142 & 0.07 & 51.5 & 27.3 & 71.9 & 43.8 \\
\hline Burke (GA) & $0.2947^{\mathrm{c}}$ & 0.3536 & 0.10 & 51.5 & 27.3 & 68.8 & 23.1 \\
\hline Terrell (GA) & $0.2906^{\mathrm{c}}$ & 0.4071 & 0.05 & 45.5 & 18.2 & 65.6 & 31.3 \\
\hline Lawrence (AL) & $0.2808^{\mathrm{c}}$ & 0.3469 & 0.06 & 51.5 & 27.3 & 62.5 & 7.7 \\
\hline Lauderdale (AL) & $0.2665^{\mathrm{c}}$ & 0.2931 & 0.06 & 42.4 & 13.6 & 62.5 & 7.7 \\
\hline Randolph (GA) & $0.2659^{c}$ & 0.3432 & 0.06 & 51.5 & 27.3 & 68.8 & 33.3 \\
\hline Jefferson (GA) & $0.2634^{\mathrm{c}}$ & 0.2874 & 0.10 & 57.6 & 36.4 & 65.6 & 31.3 \\
\hline Screven (GA) & $0.2588^{\mathrm{c}}$ & 0.2324 & 0.08 & 36.4 & 4.5 & 65.6 & 21.4 \\
\hline Irwin $(\mathrm{GA})$ & $0.2392^{\mathrm{c}}$ & 0.2767 & 0.05 & 51.5 & 27.3 & 53.1 & 16.7 \\
\hline Shelby (AL) & $0.2262^{c}$ & 0.2540 & 0.05 & 45.5 & 18.2 & 59.4 & 23.5 \\
\hline Mitchell (GA) & $0.2027^{\mathrm{c}}$ & 0.3000 & 0.05 & 45.5 & 18.2 & 53.6 & 22.2 \\
\hline Sumter (GA) & $0.1844^{\mathrm{c}}$ & 0.2226 & 0.09 & 42.4 & 13.6 & 59.4 & 18.8 \\
\hline
\end{tabular}

${ }^{\text {a }}$ Significant at the 0.01 probability level.

${ }^{\mathrm{b}}$ Significant at the 0.05 probability level.

${ }^{\mathrm{c}}$ Not significant.

near the surface did not contribute significantly to predictability of cotton yields. This supports the hypothesis that cotton yields were affected not only by rainfall but also by variables such as temperature and humid- ity affecting cotton diseases as previously explained (Fig. 6).

The predictability of cotton yields in this study is related to predictable conditions affecting rainfall and 


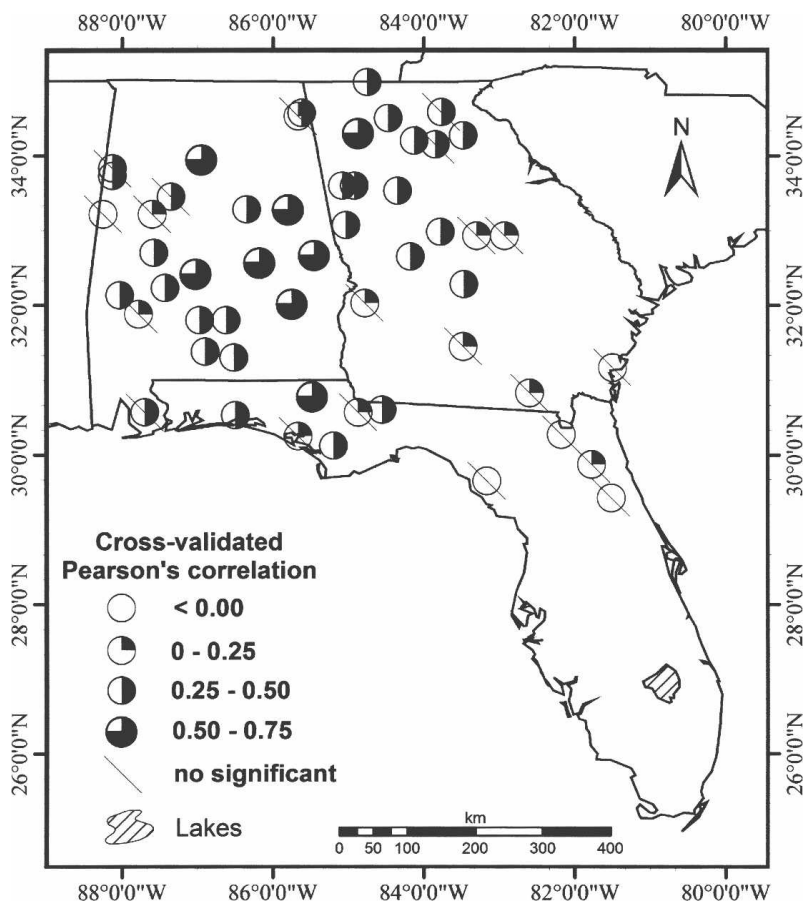

FIG. 10. Spatial distribution of the cross-validated Pearson's correlation between observed July rainfall and estimated July rainfall using meridional winds at $850 \mathrm{hPa}$ as a predictor.

humidity both through their effect on drought stress and stress caused by diseases associated with wetness. Water availability, as influenced by the amount and frequency of precipitation, is particularly important during anthesis and boll maturation, especially in sandy soils with low water retention. Irrigation during these critical periods usually increases yields (Jost et al. 2005; Marois et al. 2004); however, the same amount of water applied as rainfall may increase the risk of diseases due to leaf wetting and transmission by raindrop splash. These contrasting effects of water on cotton production make it difficult to forecast yield directly from seasonal rainfall totals alone, as found by Challinor et al. (2003) for groundnut in India.

These results demonstrate the potential use of a GCM to simulate regional atmospheric features (upper-tropospheric winds and surface temperatures) that could then be used to predict cotton yields in the Southeast. However, the ECHAM 4.5 simulations were not true predictions because the model was forced with observed, not predicted SSTs. The cotton yield results therefore represent an upper bound of predictability from the GCM forced with SST boundary conditions. Assessing operational predictability of cotton yields with a GCM will require additional studies in which SSTs are predicted, possibly comparing various methods for predicting them.

\section{Conclusions}

Specific atmospheric circulation patterns that favor high humidity, temperature, and rainfall during summer months are associated with low cotton yields in the southeast United States, consistent with the tendency of humid conditions and wet foliage to favor increased incidence of diseases during flowering and maturation. Up to $52 \%$ of the interannual variability of cotton yield in specific counties was explained from observed meridional winds at $200 \mathrm{hPa}$ and surface temperatures. The same climate predictors were significantly correlated with April and July rainfall in most of the study area. Although rainfall during this period is highly relevant to summer crops, we showed in this study that the use of the GCM simulations to estimate cotton yields was not based entirely on its ability to simulate local rainfall, and yields were not related to rainfall early in the growing season.

Cotton yield estimates from ECHAM 4.5 forced by observed SSTs in this study represented an upper bound of predictability using this GCM. Although the predictability of yields using this GCM was lower than that based on reanalysis data, $58 \%$ of the counties showed statistically significant $(p<0.05)$ potential predictability. Categorical measures of yield predictability exceeded chance in $98 \%$ of the counties. There are physical and biological relationships between cotton yield and regional atmospheric circulation patterns and surface temperatures. However, evaluation of the predictability of cotton yields that can be obtained operationally will require evaluation of the output of the GCM forced by SSTs that are forecast at the same lead time.

Acknowledgments. The research was supported by the National Oceanic and Atmospheric Administration Applied Research Center (NOAA-ARC) through Grant NA16GP1365, Subcontract FSU/UF 02081352-11 , and was developed under the auspices of the Southeast Climate Consortium; and by NOAA Grant/ Cooperative Agreement NA67GP0299. The authors thank A. Barnston, D. DeWitt, M. Bell, O. Ndiaye, and A. Mishra from the IRI, and J. Marois from UF for their support during this study. The authors thank three anonymous reviewers for their observations and advice, which helped us to improve the present paper. The retrospective forecast integration data were made possible by a computing grant from the National Center for Atmospheric Research (NCAR) Climate Simulation Laboratory (CSL) to the IRI. The views expressed in this paper are those of the authors and do not neces- 
sarily reflect the views of NOAA or any of its subagencies.

\section{REFERENCES}

Baigorria, G. A., 2007: Assessing the use of seasonal climate forecasts to support farmers in the Andean Highlands. Climate Prediction and Agriculture: Advances and Challenges, M. V. K. Sivakumar and J. W. Hansen, Eds., Springer-Verlag, 99-110.

— J. W. Jones, and J. J. O’Brien, 2006: Predicting crop yields using an ensemble of forecasts from a regional climate model. Southeast Climate Consortium Tech. Rep. Series SECC-06008, 14 pp.

,$- \ldots$, and,$- 2007 \mathrm{a}$ : Understanding rainfall spatial variability in the southeast USA at different time scales. Int. J. Climatol., 27, 749-760.

$\longrightarrow,-$ D. W. Shin, A. Mishra, and J. J. O'Brien, 2007b: Assessing uncertainties in crop model simulations using daily bias-corrected Regional Circulation Model outputs. Climate Res., 34, 211-222.

Cantelaube, P., and J. M. Terres, 2005: Seasonal weather forecasts for crop yield modelling in Europe. Tellus, 57A, 476-487.

Challinor, A. J., J. M. Slingo, T. R. Wheeler, P. Q. Craufurd, and D. I. F. Grimes, 2003: Toward a combined seasonal weather and crop production forecasting system: Determination of the working spatial scale. J. Appl. Meteor., 42, 175-192.

,,,--- and F. Doblas-Reyes, 2005: Probabilistic simulations of crop yield over western India using the DEMETER seasonal hindcast ensembles. Tellus, 57A, 498-512.

Davis, R. E., B. P. Hyden, D. A. Gay, W. L. Phillips, and G. V. Jones, 1997: The North Atlantic subtropical anticyclone. J. Climate, 10, 728-744.

Efron, B., and G. Gong, 1983: A leisurely look at the bootstrap, the jackknife, and cross-validation. Amer. Stat., 37, 36-48.

_- and R. J. Tibshirani, 1993: An Introduction to the Bootstrap. Monogr. on Statistics and Applied Probability, No. 57, Chapman and Hall, 436 pp.

Fraisse, C. W., and Coauthors, 2006: AgClimate: A climate forecast information system for agricultural risk management in the southeastern USA. Comput. Electron. Agric., 53, 13-27.

Gong, G., 1986: Cross-validation, the jackknife, and the bootstrap: Excess error estimation in forward logistic regression. $J$. Amer. Stat. Assoc., 81, 108-113.

Goodman, B., 2004: 2004 cotton outlook. Southeastern Regional Outlook Conference, Alabama Cooperative Extension System and College of Agriculture, Auburn University, 6 pp.

Hair, J. F., Jr., R. E. Anderson, R. L. Tatham, and W. C. Black, 1998: Multivariate Data Analysis. 5th ed. Prentice Hall, 799 pp.

Hansen, J. W., 2002: Realizing the potential benefits of climate prediction to agriculture: Issues, approaches, challenges. $A g$ ric. Syst., 74, 309-330.

- , 2005: Integrating seasonal climate prediction and agricultural models for insights into agricultural practice. Philos. Trans. Roy. Soc. London, 360B, 2037-2047.

_ , and M. Indeje, 2004: Linking dynamic seasonal climate forecasts with crop simulation for maize yield prediction in semiarid Kenya. Agric. For. Meteor., 125, 143-157.

_ A. W. Hodges, and J. W. Jones, 1998: ENSO influences on agriculture in the southeastern United States. J. Climate, 11, 404-411.
Higgins, R. W., K. C. Mo, and Y. Yao, 1998: Interannual variability of the U.S. summer precipitation regime with emphasis on the southwestern monsoon. J. Climate, 11, 2582-2606.

Hsieh, W. W., B. Y. Tang, and E. R. Garnett, 1999: Teleconnections between Pacific seas surface temperatures and Canadian prairie wheat yield. Agric. For. Meteor., 96, 209-217.

Ibarra, R., and T. Hewitt, 1999: Utilizing crop insurance to reduce production risk. Institute of Food and Agricultural Sciences Publication FE-198, Florida Cooperative Extension Service, 3 pp.

Ines, A. V. M., and J. W. Hansen, 2006: Bias correction of daily GCM rainfall for crop simulation studies. Agric. For. Meteor., 138, 44-53.

Ingram, K. T., M. C. Roncoli, and P. H. Kirshien, 2002: Opportunities and constraints for farmers of west Africa to use seasonal precipitation forecasts with Burkina Faso as a case study. Agric. Syst., 74, 331-349.

Jagtap, S. S., J. W. Jones, P. Hildebrand, D. Letson, J. J. O'Brien, G. Podestá, D. Zierden, and F. Zazueta, 2002: Responding to stakeholder's demands for climate information: From research to applications in Florida. Agric. Syst., 74, 415-430.

Jost, P. H., S. M. Brown, S. Culpepper, G. Harris, B. Kemerait, P. Roberts, D. Shurley, and J. Williams, 2005: 2005 Georgia cotton production guide. Cooperative Extension Service/The University of Georgia, College of Agricultural and Environmental Sciences Bulletin CSS-05-01, No. 1275, 39 pp.

Kalnay, E., and Coauthors, 1996: The NCEP/NCAR 40-Year Reanalysis Project. Bull. Amer. Meteor. Soc., 77, 437-471.

Klein, W. H., 1957: Principal tracks and mean frequencies of cyclones and anticyclones in the Northern Hemisphere. Weather Bureau Research Paper 40, 60 pp.

Krzanowski, W. J., 1987: Cross-validation in principal component analysis. Biometrics, 43, 575-584.

Mailhot, D., J. Marois, and D. Wright, 2005: Association of flower thrips with Fusarium verticillioides. Phytopathology, 95 (6).

Marletto, V., and Coauthors, 2005: Evaluation of downscaled DEMETER multi-model ensemble seasonal hindcasts in a northern Italy location by means of a model of wheat growth and soil water balance. Tellus, 57A, 488-497.

Marois, J. J., D. L. Wright, P. J. Wiatrak, and M. A. Vargas, 2002: Association of Fusarium sp. with Hardlock of cotton in the southeastern U.S. Proc. Beltwide Cotton Conf., Nashville, TN, National Cotton Council, CO17.

,,,--- and M. A. Vargas, 2004: Effect of row width and nitrogen on cotton morphology and canopy microclimate. Crop Sci., 44, 870-877.

—, T. W. Katsvairo, D. L. Wright, and P. P. Wiatrak, 2005: Cotton Hardlock update. Proc. Management of Miscellaneous Crops, ASA-CSSA-SSSA Int. Meeting, Salt Lake City, UT, ASA, CSSA, and SSSA, 310.

Murphy, A. H., 1993: What is a good forecast? An essay on the nature of goodness in weather forecasting. Wea. Forecasting, 8, 281-293.

Nelson, R. A., D. P. Holzworth, G. L. Hammer, and P. T. Hayman, 2002: Infusing the use of seasonal climate forecasting into crop management practice in North East Australia using discussion support software. Agric. Syst., 74, 393-414.

Phillips, J. G., D. Deane, L. Unganai, and A. Chimeli, 2002: Implications of farm-level response to seasonal climate forecasts for aggregate grain production in Zimbabwe. Agric. Syst., 74, 351-369.

Podestá, G., and Coauthors, 2002: Use of ENSO-related climate 
information in agricultural decision making in Argentina: A pilot experience. Agric. Syst., 74, 371-392.

Press, W. H., B. P. Flannery, S. A. Teukolsky, and W. T. Vetterling, 1989: Numerical Recipes: The Art of Scientific Computing. Cambridge University Press, 702 pp.

Roeckner, E., and Coauthors, 1996: The atmospheric general circulation model ECHAM4: Model description and simulation of present-day climate. Max Planck Institut für Meteorologie Rep. 218, 90 pp.

Sahsamanoglou, H. S., 1990: A contribution to the study of action centres in the North Atlantic. Int. J. Climatol., 10, 247-261.
Shin, D. W., J. G. Below, T. E. LaRow, S. Cocke, and J. J. O'Brien, 2006: The role of an advance land model in seasonal dynamical downscaling for crop model application. J. Appl. Meteor. Climatol., 45, 686-701.

Stahle, D. W., and M. K. Cleaveland, 1992: Reconstruction and analysis of spring rainfall over the southeastern U.S. for the past 1000 years. Bull. Amer. Meteor. Soc., 73, 1947-1961.

USDA National Agricultural Statistics Service, 2004: Crop values: Final estimates 1997-2002. Statistical Bulletin, No. 999a, 70 pp.

Wilks, D. S., 2006: Statistical Methods in the Atmospheric Sciences. 2nd ed. Academic Press, 627 pp. 